\title{
Preservation of Microbial Lipids in Geothermal Sinters
}

\author{
Gurpreet Kaur, ${ }^{1}$ Bruce W. Mountain, ${ }^{2}$ Ellen C. Hopmans, ${ }^{3}$ and Richard D. Pancost ${ }^{1}$
}

\begin{abstract}
Lipid biomarkers are widely used to study the earliest life on Earth and have been invoked as potential astrobiological markers, but few studies have assessed their survival and persistence in geothermal settings. Here, we investigate lipid preservation in active and inactive geothermal silica sinters, with ages of up to 900 years, from Champagne Pool, Waiotapu, New Zealand. Analyses revealed a wide range of bacterial biomarkers, including free and bound fatty acids, 1,2-di-O-alkylglycerols (diethers), and various hopanoids. Dominant archaeal lipids include archaeol and glycerol dialkyl glycerol tetraethers (GDGTs). The predominance of generally similar biomarker groups in all sinters suggests a stable microbial community throughout Champagne Pool's history and indicates that incorporated lipids can be well preserved. Moreover, subtle differences in lipid distributions suggest that past changes in environmental conditions can be elucidated. In this case, higher archaeol abundances relative to the bacterial diethers, a greater proportion of cyclic GDGTs, the high average chain length of the bacterial diethers, and greater concentrations of hopanoic acids in the older sinters all suggest hotter conditions at Champagne Pool in the past. Key Words: Extremophiles-Silica sinters-Lipid biomarkersArchaeol-Bacterial diethers - Fatty acids. Astrobiology 11, 259-274.
\end{abstract}

\section{Introduction}

$\mathbf{M}$ UCH ATTENTION has been devoted to identifying life signatures in geothermal environments. Such systems have been suggested as primary models for Mars exploration and were recently highlighted as a target by the UK planetary science community (Cockell et al., 2009). Moreover, the identification of the limits of life here on Earth and the survival mechanisms utilized by organisms that thrive in these harsh environments is vital to our understanding of the origins and diversification of life on Earth and throughout the Solar System.

Current astrobiological and origin-of-life investigations focus on the detection of microbial remains preserved in rocks. Indeed, the ability to recognize the signature of life in rocks from Earth's fossil record as well as in extraterrestrial materials is one of the primary goals in the NASA Astrobiology Roadmap (Des Marais et al., 2008). Geothermal systems are commonly host to silica deposits, which form rapidly and often preserve a chemical signal of the spring inhabitants. As such, silica sinters and their associated microbiology have been studied in a range of hot springs in Yellowstone National Park, USA (e.g., Jahnke et al., 2001; Blank et al., 2002; Guidry and Chafetz, 2003), Krisuvik, Iceland (e.g., Schultzelam et al., 1995; Konhauser et al., 2001) and the Taupo Volcanic Zone, New Zealand (e.g., Jones et al., 2001; Mountain et al., 2003). DNA and RNA in these settings are typically poorly preserved, and progressive silicification can destroy morphological details, which makes identification of fossilized microorganisms in geothermal deposits difficult (Jones et al., 1997).

Lipid biomarkers, which are characterized by a wide variety of hydrocarbon structures, serve as powerful tools in the characterization of microbial community structure in diverse environments. Their structures have been well preserved throughout geological time, such that they have been extensively utilized as indictors of past biological activity on Earth (e.g., Summons et al., 1996; Freeman, 2001; Hayes, 2001; Simoneit, 2002) and in some cases used to characterize past microbial communities (e.g., Thiel et al., 2001; Peckmann and Thiel, 2004; Brocks et al., 2005; Birgel et al., 2006). Recently, it was shown that lipid biomarkers appear to be well preserved in geothermal sinters, with rapid silicification aiding geochemical preservation (Pancost et al., 2005, 2006; Talbot et al., 2005; Gibson et al., 2008; Kaur et al., 2008), and it was proposed that such compounds, once encased in the silica matrix, could persist for extended periods of time. Since the structure and distributions of the membrane lipids reflect the chemical and microbiological conditions present during the time of sinter formation, it follows that these compounds

\footnotetext{
${ }^{1}$ Organic Geochemistry Unit, Bristol Biogeochemistry Research Centre, School of Chemistry, University of Bristol, Bristol, UK.

${ }^{2}$ GNS Science, Wairakei Research Centre, Taupo, New Zealand.

${ }^{3}$ Royal Netherlands Institute for Sea Research, Department of Marine Organic Biogeochemistry, Texel, the Netherlands.
} 
Table 1. Chemical Composition of Water from Champagne Pool

\begin{tabular}{lcccccccccccccccc}
\hline $\mathrm{T}\left({ }^{\circ} \mathrm{C}\right)$ & $\mathrm{pH}$ & $\mathrm{Na}$ & $\mathrm{K}$ & $\mathrm{Li}$ & $\mathrm{Ca}$ & $\mathrm{Mg}$ & $\mathrm{As}$ & $\mathrm{Cl}$ & $\mathrm{F}$ & $\mathrm{SiO}_{2}$ & $\mathrm{Sb}$ & $\mathrm{Fe}$ & $\mathrm{Al}$ & $\mathrm{SO}_{4}$ & $\mathrm{HCO}_{3}$ & $\mathrm{H}_{2} \mathrm{~S}$ \\
\hline 75.5 & 5.5 & 1145 & 163 & 8.8 & 35.2 & 0.05 & 5.3 & 1922 & 4.1 & 430 & 3.5 & 0.05 & 0.4 & 261 & 180 & 7 \\
\hline
\end{tabular}

Units are in ppm, except Sb (in ppb). Data from Phoenix et al. (2005) and Mountain et al. (2003).

could be used to assess past spring chemistry and microbiology. For example, monomethyl alkanes record the presence of cyanobacteria (Shiea et al., 1990); archaeal lipids, specifically glycerol dialkyl glycerol tetraethers (GDGTs), are predominant at high temperatures and low $\mathrm{pH}$ (Robertson et al., 2005), and longer-chain fatty acids and saturated components are more abundant at higher temperatures (Weerkamp and Heinen, 1972; Russell, 1984; Zeng et al., 1992).

This paper focuses on the lipids preserved in both active and inactive silica sinters from Champagne Pool, a geothermal spring located in the Taupo Volcanic Zone (TVZ), New Zealand, and expands on results published in our previous paper, Kaur et al. (2008). Active sinters are defined as those precipitating at the air-water interface, whereas inactive sinters are those that are no longer precipitating in the spring. These inactive deposits would have initially formed at the pool edge, and, as a result of subsequent deposition of silica and contraction of the spring over time, they are now in non-geothermal settings and no longer precipitating. Thus, they have the potential to record past geothermal conditions. Accordingly, this work has three primary goals: (1) assess microbial lipid preservation in active geothermal silica sinters and their ability to record extant microbial populations; (2) utilize lipid profiles to assess the preservation of lipids in inactive sinter and investigate past variations in microbial community structure and environmental conditions; and (3) identify novel biomarker-based tools that may have particular chemotaxonomic potential or offer insight into survival strategies in such extremes.

\section{Experimental Methods}

\subsection{Sample details}

The TVZ is situated centrally on the North Island of New Zealand. Up to $60 \mathrm{~km}$ wide and extending approximately $300 \mathrm{~km}$ from the Tongariro and Ruapehu volcanic centers on the North Island to the active White Island volcano located $50 \mathrm{~km}$ offshore, the TVZ is the largest and most active rhyolitic magmatic system on Earth (Houghton et al., 1995). This extensive volcanism is coupled with several high-temperature $\left(>250^{\circ} \mathrm{C}\right)$ geothermal systems, including the Waiotapu geothermal system in which Champagne Pool is located. The pool occupies a hydrothermal explosion crater formed approximately 900 years ago (Lloyd, 1959). It is approximately $60 \mathrm{~m}$ in diameter, $150 \mathrm{~m}$ in depth, and has a surface area of $3000 \mathrm{~m}^{2}$. The spring water is anoxic and of a mildly acid chloride type, with a $\mathrm{pH}$ of 5.5 and a constant temperature of approximately $75^{\circ} \mathrm{C}$. This slight acidity is partly due to the upward flow of dissolved $\mathrm{CO}_{2}$ from the deep geothermal aquifer. The spring has a high gas flux, largely $\mathrm{CO}_{2}(82.1 \%)$ with relatively high $\mathrm{H}_{2} \mathrm{~S}$ concentrations $(7.2 \%$ ) (Phoenix et al., 2005). It is supersaturated with respect to amorphous silica (430 mg kg-1 $\mathrm{SiO}_{2}$; Mountain et al., 2003) and contains a wide array of trace elements, including $\mathrm{Au}, \mathrm{Ag}, \mathrm{Sb}, \mathrm{W}$, and
As (Jones et al., 2001; Table 1). Above the air-water interface, spicular sinters surround the pool. These are predominantly composed of amorphous silica that occurs as porous and nonporous laminae, the former containing silicified filamentous and nonfilamentous microbes (Mountain et al., 2003).

In total, 16 samples, CPa1-CPa16, were collected from this system (Table 2; Fig. 1). CPa1-CPa4 are active sinters (precipitating at the air-water interface) collected from different margins of the pool. $\mathrm{CPa} 5-\mathrm{CPa} 16$ represent inactive sinters sampled at increasing distances from the spring (Fig. 1). Distance from the pool correlates with sinter age, owing to radial deposition of silica and contraction of the pool over time. CPa16 represents the oldest sinter of those collected, which is located approximately $20 \mathrm{~m}$ from the pool edge and estimated to be around 900 years old, the approximate time that Champagne Pool was formed (Lloyd, 1959). Note that samples $\mathrm{CPa} 15$ and CPa16 were fragmented and partially buried in the surrounding soil, providing the opportunity to examine the persistence of the geothermal signal into weathered sinter.

\subsection{Lipid analysis}

Samples were pre-extracted with dichloromethane (DCM)/methanol (MeOH) (1:1 v/v) prior to workup, such that the compounds identified likely derive from microorganisms encased in the silica matrix (Pancost et al., 2005)

Table 2. Sample Locations

\begin{tabular}{cl}
\hline $\mathrm{CPa}$ & \multicolumn{1}{c}{ Location } \\
\hline 1 & Active sinter from west margin \\
2 & Active sinter from north margin \\
3 & Active sinter from west margin \\
4 & Active sinter from south margin \\
5 & Inactive sinter close to CPa1 (inner rim) \\
6 & Inactive sinter on highest level on sinter wall \\
7 & Inactive sinter from sinter ledge, below \\
& CPa6 (outer wall) \\
8 & Inactive sinter from sinter ledge, below \\
& CPa7 (outer wall) \\
9 & Inactive sinter from sinter ledge, below \\
& CPa8 (outer wall) \\
10 & Inactive sinter from sinter ledge, below \\
& CPa9 (outer wall) \\
11 & Inactive sinter from sinter ledge, next to \\
& CPa10 (outer wall) \\
12 & Inactive sinter $\sim 2 \mathrm{~m}$ from pool \\
13 & Inactive sinter next to CPa12 \\
14 & Inactive sinter next to CPa13 \\
15 & Weathered, inactive sinter $\sim 8 \mathrm{~m}$ from pool \\
16 & Weathered, inactive sinter $\sim 20 \mathrm{~m}$ from pool \\
\hline
\end{tabular}




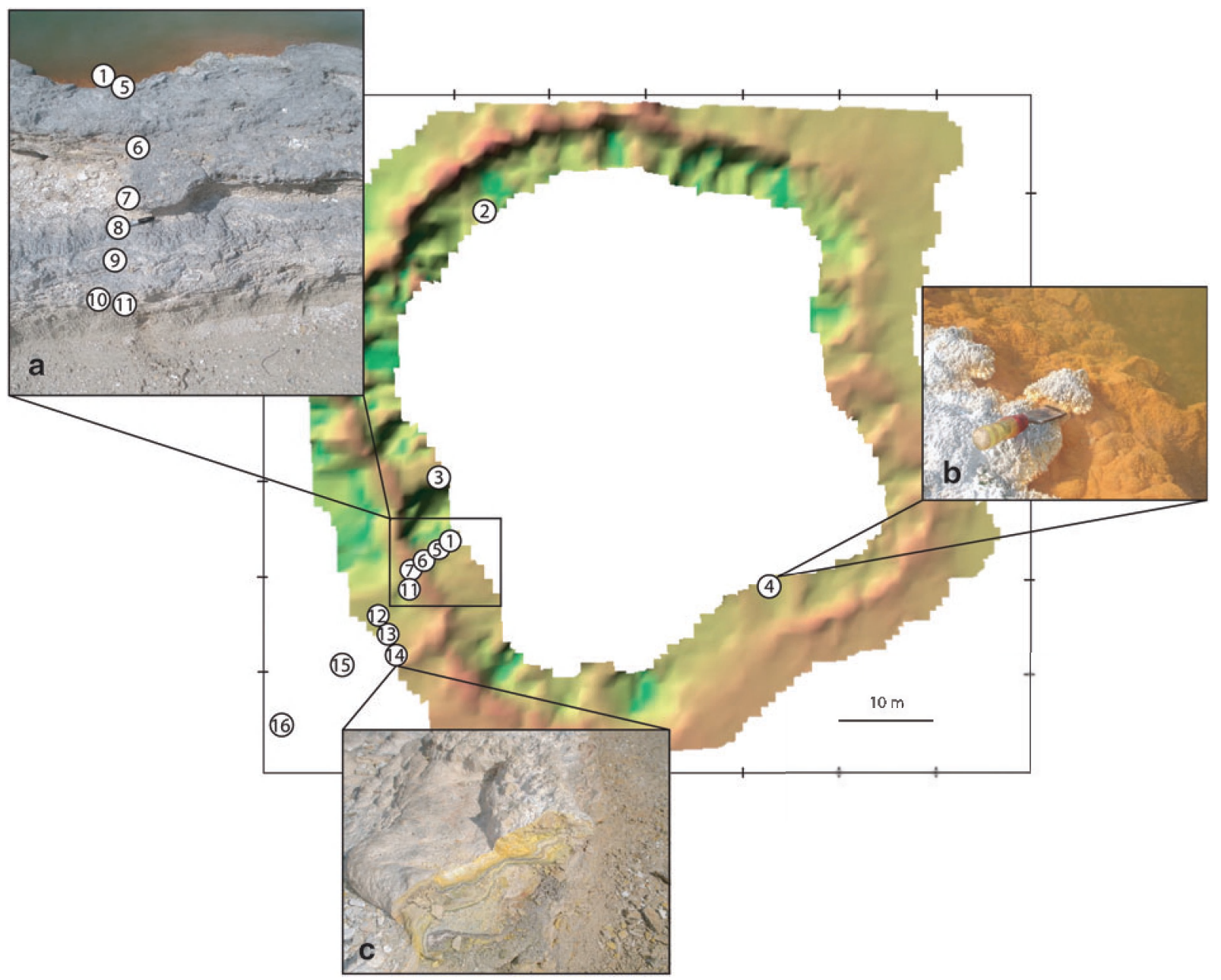

FIG. 1. Map of Champagne Pool's rim and sinter wall, marking locations of CPa1-CPa16. Inserts show (a) the west margin of the pool, marking collection sites of CPa1 at the pool edge and CPa5-CPa11 on sinter wall (field of view is $1 \mathrm{~m}$ ); (b) the morphology and texture of active sinter CPa4 (field of view is $40 \mathrm{~cm}$ ); (c) the morphology and texture of inactive sinter CPa14 (field of view is $30 \mathrm{~cm}$ ). Details of collection sites are given in Table 2. Color images available online at www.liebertonline.com/ast

rather than post-lithification endoliths or, in the case of CPa15 and CPa16, soil bacteria or archaea. Lipids are present in the pre-extracts but are of lower abundance than in the samples, which suggests that background contamination of the latter is minimal. Samples were dried, ground to fine powder, and sequentially extracted by sonication with DCM, $\mathrm{DCM} / \mathrm{MeOH}(1: 1 \mathrm{v} / \mathrm{v})$, and $\mathrm{MeOH}$. Activated copper turnings were then added to the lipid extracts and left for $24 \mathrm{~h}$ to remove elemental sulfur. An aliquot $(50 \%)$ of the total lipid extract was fractionated by using aminopropyl solid phase extraction columns (Phenomenex; $\mathrm{NH}_{2}, 500 \mathrm{mg}, 6 \mathrm{~mL}$ ). The fractions were eluted sequentially with $12 \mathrm{~mL} \mathrm{DCM} /$ isopropanol $(2: 1 \mathrm{v} / \mathrm{v}$; neutral fraction, containing, e.g., hydrocarbons, bacterial diethers, archaeol, GDGTs), $12 \mathrm{~mL}$ of $5 \%$ acetic acid in ether (acid fraction, containing, e.g., free fatty acids, hopanoic acids, and possibly glycolipids), and $24 \mathrm{~mL}$ of $\mathrm{MeOH}$ (polar and inferred glyco- and phospholipid fraction). Subsequently, $5 \alpha$-androstane and hexadecan-2-ol ( $200 \mathrm{ng}$ ) were added to the neutral fraction as internal standards. The neutral fraction was then further separated into neutral apolar (containing hydrocarbons) and neutral polar (containing alcohols, bacterial diethers, archaeol, and
GDGTs) fractions by elution through an activated alumina column with hexane/DCM $(9: 1 \mathrm{v} / \mathrm{v})$ and DCM/MeOH $(1: 2$ $\mathrm{v} / \mathrm{v}$ ), respectively.

The glycolipid and phospholipid fatty acid components were released by saponification. Due to the possibility of some glycolipids eluting in the acid fraction, both acid and polar fractions were saponified. Fractions were heated with $1 \mathrm{~mL}$ of fresh $0.5 \mathrm{M} \mathrm{95 \%}$ methanolic $\mathrm{NaOH}$ at $70^{\circ} \mathrm{C}$ for $1 \mathrm{~h}$. The hydrolyzed mixture was left to cool and acidified to $\mathrm{pH}$ 1-2 with $1 \mathrm{M} \mathrm{HCl}(\sim 1 \mathrm{~mL})$, then extracted with hexane $(3 \times 2 \mathrm{~mL})$, combined and evaporated under $\mathrm{N}_{2}$. The fatty acids were methylated by using $100 \mu \mathrm{L} \mathrm{BF}_{3} / \mathrm{MeOH}$ solution at $70^{\circ} \mathrm{C}$ for $1 \mathrm{~h}$. After cooling, $1 \mathrm{~mL}$ of double-distilled water was added, and the methyl esters were extracted with DCM as above. The fatty acid methyl esters were dissolved in approximately $1 \mathrm{~mL}$ of DCM and eluted through a prewashed anhydrous $\mathrm{Na}_{2} \mathrm{SO}_{4}$ column to remove residual water. An $n-\mathrm{C}_{19}$ standard was added, and the fractions were dried under $\mathrm{N}_{2}$.

2.2.1. Gas chromatography and gas chromatographymass spectrometry. Before analysis, neutral polar and 
methyl esterified acid and polar fractions were derivatized with $25 \mu \mathrm{L}$ pyridine and $25 \mu \mathrm{L}$ BSTFA $\left(70^{\circ} \mathrm{C}, 1 \mathrm{~h}\right)$ to convert hydroxyl functional groups into trimethylsilyl ethers; the latter two fractions were silylated in order to quench hydroxyl groups in hydroxy fatty acids. Samples were analyzed by a Carlo Erba Instrument HRGC 5300 Megaseries gas chromatograph equipped with a Chrompack CP SIL-5CB capillary column $(50 \mathrm{~m} \times 0.32 \mathrm{~mm}$ i.d.; $0.12 \mu \mathrm{m}$ film, dimethylpolysiloxane equivalent) and a flame ionization detector. Hydrogen was used as the carrier gas, and samples were injected at $70^{\circ} \mathrm{C}$ with a temperature program of $20^{\circ} \mathrm{C}$ $\mathrm{min}^{-1}$ to $130^{\circ} \mathrm{C}$, and $4^{\circ} \mathrm{C} \mathrm{min}$ min $^{-1}$ to $300^{\circ} \mathrm{C}$ (held for $25 \mathrm{~min}$ ). Gas chromatography-mass spectrometry analyses were performed by using a Thermo Finnigan Trace gas chromatograph interfaced to a Trace mass spectrometer. The gas chromatograph column and temperature program were the same as those described previously. Electron impact ionization $(70 \mathrm{eV})$ was used, and full scan spectra were obtained by scanning the range $m / z 50-800$ at 1 scan s $^{-1}$.

2.2.2 Liquid chromatography-mass spectrometry. Samples were analyzed by high performance liquid chromatography/atmospheric pressure chemical ionization-mass spectrometry based on a procedure modified from Hopmans et al. (2000) and by using an Agilent 1100 series/Hewlett-Packard 1100 MSD series instrument equipped with an auto-injector and Chemstation software. Separation was achieved on a Prevail Cyano column (2.1 i.d. $\times 150 \mathrm{~mm}, 3 \mu \mathrm{m}$; Alltech), maintained at $30^{\circ} \mathrm{C}$. Typical injection volume was $10 \mu \mathrm{L}$. GDGTs were eluted isocratically with $99 \%$ hexane and $1 \%$ isopropanol for $5 \mathrm{~min}$, followed by a linear gradient to $1.6 \%$ isopropanol for $40 \mathrm{~min}$. Flow rate was set at $0.2 \mathrm{~mL} \mathrm{~min} \mathrm{~min}^{-1}$. After each analysis, the column was cleaned by back-flushing hexane/propanol $(95: 5, \mathrm{v} / \mathrm{v})$ at $0.2 \mathrm{~mL} \mathrm{m^{-1 }}$ for $10 \mathrm{~min}$. Detection was achieved by using positive-ion atmospheric pressure chemical ionization of the eluent. Conditions for the Agilent 1100 atmospheric pressure chemical ionization-mass spectrometer were as follows: nebulizer pressure $60 \mathrm{psi}$, vaporizer temperature $400^{\circ} \mathrm{C}$, drying gas $\left(\mathrm{N}_{2}\right)$ flow $6 \mathrm{~L} \mathrm{~min}{ }^{-1}$ and temperature $200^{\circ} \mathrm{C}$, capillary voltage $-3.5 \mathrm{kV}$, corona current $5 \mu \mathrm{A}$. Positive ion spectra were generated by scanning from $m / z 900$ to 1400 .

\section{Results}

Biomarker concentrations and distributions are highly variable among the sinters from Champagne Pool. Bacterial biomarkers include free fatty acids (Appendix Ia), bound fatty acids (I), 1,2-di-O-alkylglycerols (diethers, V), and various hopanoids (IV); and dominant archaeal lipids include archaeol (VI) and GDGTs (VII). Also present in subordinate abundance are n-alkanes, n-alkanols, wax esters, sterols, and polyaromatic hydrocarbons (Fig. 2). The distributions of $n$-alkanes (odd-over-even predominance) and n-alkanols (even-over-odd predominance) are consistent with a minor higher plant input (Eglinton et al., 1962). Sterols

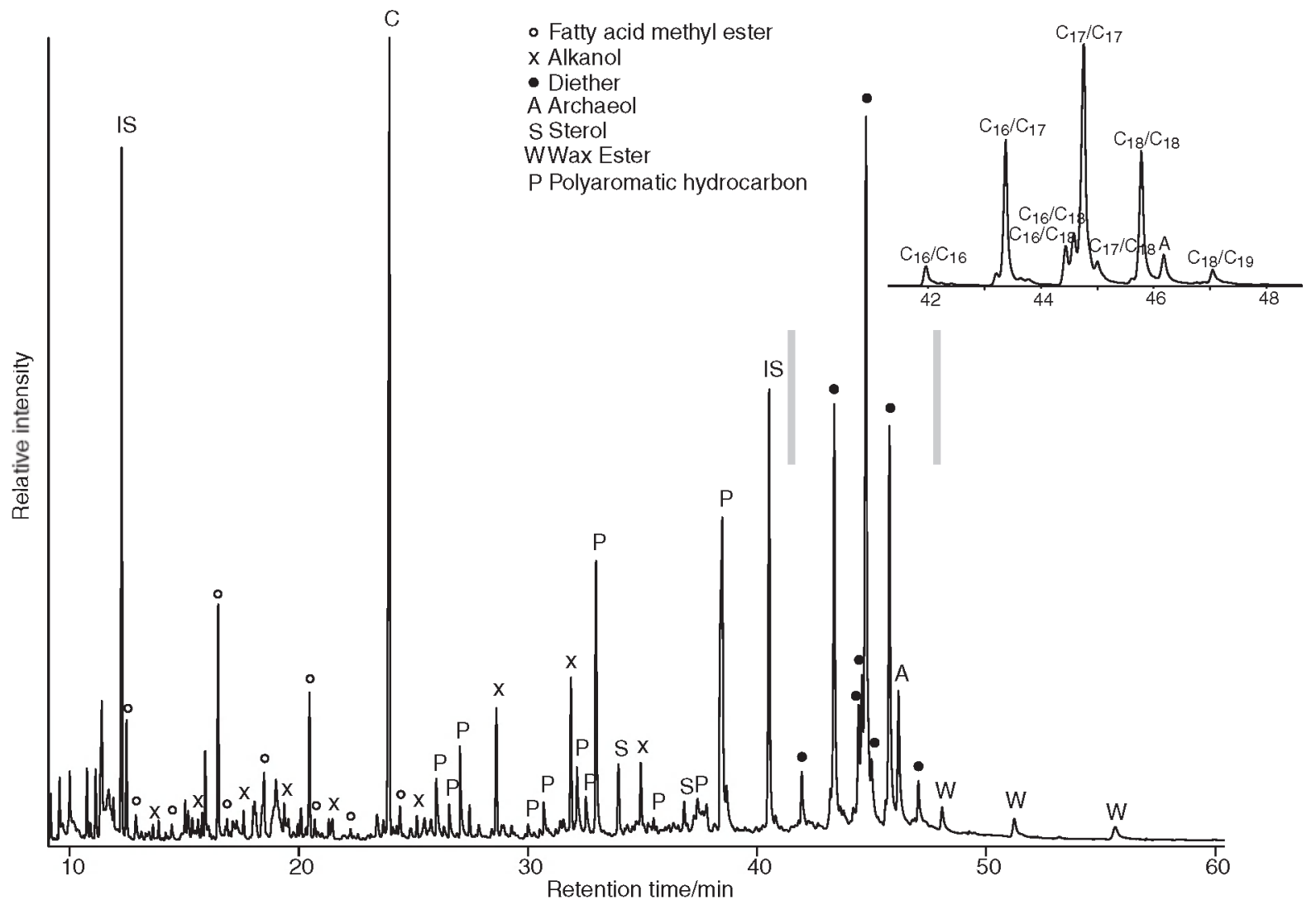

FIG. 2. Partial gas chromatogram showing the neutral polar fraction of an inactive sinter (CPa5); inset shows the partial $m / z$ 133 mass chromatogram and distribution of bacterial diethers. Note IS denotes internal standard and C denotes contamination by phthalate. 
and wax esters (Fig. 2), although present in mildly thermophilic algae and Chloroflexus, respectively (Shiea et al., 1991; van der Meer et al., 2000; Summons et al., 2006), are likely of allochthonous higher plant origin due to the unfavorable growth conditions for potential source-organisms at Champagne Pool. Polyaromatic hydrocarbons are likely associated with geothermal fluids (Simoneit, 2002) and derive from organic material altered in the subsurface. For these reasons, these compound classes are not discussed further, and we focus solely on the concentrations and distributions of lipids of inferred bacterial and archaeal origin.

\subsection{Bacterial diether lipids}

Dialkyl glycerol diethers (V, 1,2-di-O-alkylglycerols) are among the predominant membrane lipids in some thermophilic bacterial species, including Aquificales (Huber et al., 1992; Jahnke et al., 2001), Ammonifex degensii (Huber et al., 1996), and Thermodesulfobacterium commune (Langworthy et al., 1983), but have also been identified in nonthermophilic members of the order Planctomycetes (Sinninghe Damsté et al., 2005) and, more recently, myxobacteria (Ring et al., 2006). Their occurrence in geothermal environments, including sinters and mats, has been previously reported (Zeng et al., 1992; Jahnke et al., 2001; Pancost et al., 2005, 2006). A range of bacterial ether lipids comprising non-isoprenoidal alkyl components were identified in the neutral polar fraction from the Champagne Pool sinters (Table 3, Fig. 2), with their respective alkyl chain lengths (straight chain or methylbranched) tentatively identified on the basis of retention times and mass spectra (Pancost et al., 2001, 2006). Total concentrations are highly variable, ranging from 0.004 in $\mathrm{CPa} 7$ to $3.4 \mathrm{mg} \mathrm{g}^{-1}$ total organic carbon (TOC) in CPa10 (Table 3, Fig. 3a). Although the total bacterial diether concentration shows no obvious trend with increasing age, the lowest concentrations generally occur in the oldest sinters CPa14-CPa16 (Fig. 3a). In fact, of the 16 sinters analyzed from Champagne Pool, $\mathrm{CPa} 14$ and $\mathrm{CPa} 16$ are the only sinters where bacterial diethers were not detected. Where present, the predominant bacterial diethers are typically the $\mathrm{C}_{16} / \mathrm{C}_{17}$, $\mathrm{C}_{17} / \mathrm{C}_{17}$, and $\mathrm{C}_{18} / \mathrm{C}_{18}$ components (subscripts denote the carbon chain length of the two alkyl moieties; Table 3), but their distributions vary with sample age (Fig. 3b). Diether average chain length (ACL; defined as the mean number of carbon atoms in the component alkyl chains) generally increases with sample age (Fig. 3c), and the dominant diether lipid shifts from $C_{17} / C_{17}$ in the active and younger inactive sinters to $\mathrm{C}_{18} / \mathrm{C}_{18}$ in the older ones (Fig. $3 \mathrm{~b}$ ). Furthermore, in the oldest sinters, diethers bearing $\mathrm{C}_{16}$ alkyl components were not detected (Table 3).

\subsection{Archaeal lipids}

Archaeol (VI), a diether lipid comprising isoprenoid alkyl chains, is widely distributed among archaea (DeRosa and Gambacorta, 1988) and has been previously identified in geothermal sinters and microbial mats (Ward et al., 1985; Pancost et al., 2005, 2006). Although the concentration of archaeol in the Champagne Pool sinters is highly variable, ranging from 0.008 in $\mathrm{CPa} 3$ to $0.29 \mathrm{mg} \mathrm{g}^{-1} \mathrm{TOC}$ in $\mathrm{CPa} 1$ and CPa15 (Table 3), samples CPa12-CP15 show considerably higher concentrations than the active and younger inactive sinters with the exception of $\mathrm{CPa} 1$. In sinters $\mathrm{CPa} 1-\mathrm{CPa} 13$, archaeol is generally much less abundant than the bacterial diethers and present in concentrations typically an order of magnitude lower (Table 3; Fig. 3a). In the older sinters, however, archaeol concentrations are higher, and in CPa14CPa16 archaeol concentrations exceed those of the cooccurring bacterial diethers (Fig. 3a, 3c).

Isoprenoid GDGTs (VIIa-d), comprising biphytanyl (C40) moieties, are characteristic core lipid components of many archaea (DeRosa and Gambacorta, 1988). They are the predominant membrane lipids of some hyperthermophilic archaea and have been identified in geothermal sinters, mats, and sediment (Ward et al., 1985; Pearson et al., 2004; Pancost et al., 2006; Zhang et al., 2006; Schouten et al., 2007). A selection of the Champagne Pool sinters was analyzed for GDGTs: CPa1, CPa5, CPa6, CPa7, CPa11, CPa13, CPa14, $\mathrm{CPa} 15$, and $\mathrm{CPa} 16$. In all sinters analyzed, an array of isoprenoid tetraether lipids, comprising $0-7$ cyclopentyl rings (Table 4; Fig. 4), was identified on the basis of mass spectra. GDGTs with 0-4 cyclopentane rings are typically dominant (Fig. 4), but their distributions vary with sample age. In CPa1 and CPa5, distributions are dominated by GDGT-0 (VIIa),

Table 3. Concentration ( $\mathrm{Mg} \mathrm{G}^{-1}$ TOC) and Distributions of Archaeol and Bacterial Diethers Recovered from Neutral Polar Fractions from Champagne Pool Sinters

\begin{tabular}{llllllllllllllllll}
\hline & CPa1 & CPa2 & CPa3 & CPa4 & CPa5 & CPa6 & CPa7 & CPa8 & CPa9 & CPa10 & CPa11 & CPa12 & CPa13 & CPa14 & CPa15 & CPa16 \\
\hline $\mathrm{C}_{16} / \mathrm{C}_{16}$ & - & 0.007 & 0.002 & - & 0.01 & - & - & 0.01 & 0.03 & - & 0.01 & 0.01 & - & - & - & - \\
$\mathrm{C}_{16} / \mathrm{C}_{17}$ & 0.31 & 0.07 & 0.01 & 0.03 & 0.10 & 0.05 & - & 0.03 & 0.06 & 0.19 & 0.02 & 0.13 & 0.06 & - & - & - \\
$\mathrm{C}_{16} / \mathrm{C}_{18}$ & 0.32 & 0.02 & 0.004 & - & 0.06 & 0.03 & - & 0.04 & 0.27 & 0.69 & 0.06 & 0.19 & 0.14 & - & - & - \\
$\mathrm{C}_{17} / \mathrm{C}_{17}$ & 1.2 & 0.24 & 0.04 & 0.05 & 0.18 & 0.09 & 0.003 & 0.10 & 0.15 & 0.57 & 0.03 & 0.43 & 0.12 & - & 0.02 & - \\
$\mathrm{C}_{17} / \mathrm{C}_{18}$ & 0.19 & 0.02 & 0.003 & 0.008 & 0.02 & 0.009 & - & 0.008 & - & - & 0.01 & 0.04 & 0.06 & - & - & - \\
$\mathrm{C}_{18} / \mathrm{C}_{18}$ & 0.63 & 0.07 & 0.01 & 0.02 & 0.09 & 0.05 & 0.002 & 0.10 & 0.40 & 1.8 & 0.07 & 0.61 & 0.18 & - & 0.02 & - \\
$\mathrm{C}_{18} / \mathrm{C}_{19}$ & 0.10 & 0.009 & 0.001 & - & 0.01 & 0.005 & - & 0.010 & 0.03 & 0.21 & 0.006 & 0.05 & 0.03 & - & 0.003 & - \\
TOTAL & 2.7 & 0.44 & 0.07 & 0.10 & 0.46 & 0.23 & 0.004 & 0.29 & 0.94 & 3.4 & 0.20 & 1.5 & 0.60 & - & 0.04 & - \\
ACL & 17.3 & 17.1 & 17.1 & 17.1 & 17.1 & 17.2 & 17.4 & 17.3 & 17.4 & 17.6 & 17.3 & 17.4 & 17.4 & - & 17.6 & - \\
Archaeol & 0.29 & 0.04 & 0.008 & 0.01 & 0.04 & 0.02 & 0.01 & 0.03 & 0.09 & 0.17 & 0.01 & 0.18 & 0.14 & 0.27 & 0.29 & 0.07 \\
Diethers/ & 9.4 & 11.9 & 9.7 & 10.6 & 13.0 & 9.3 & 0.40 & 9.7 & 10.9 & 20.2 & 16.9 & 7.9 & 4.2 & 0.00 & 0.15 & 0.00 \\
$\quad$ archaeol & & & & & & & & & & & & & & & \\
TOC (\%) & 0.38 & 0.80 & 0.54 & 0.98 & 0.38 & 0.31 & 0.40 & 0.46 & 0.22 & 0.29 & 0.12 & 0.39 & 0.17 & 0.21 & 0.32 & 0.21 \\
\hline
\end{tabular}

Note samples have been renamed since Kaur et al. (2008) to include additional samples and to maintain the chronological ordering. 

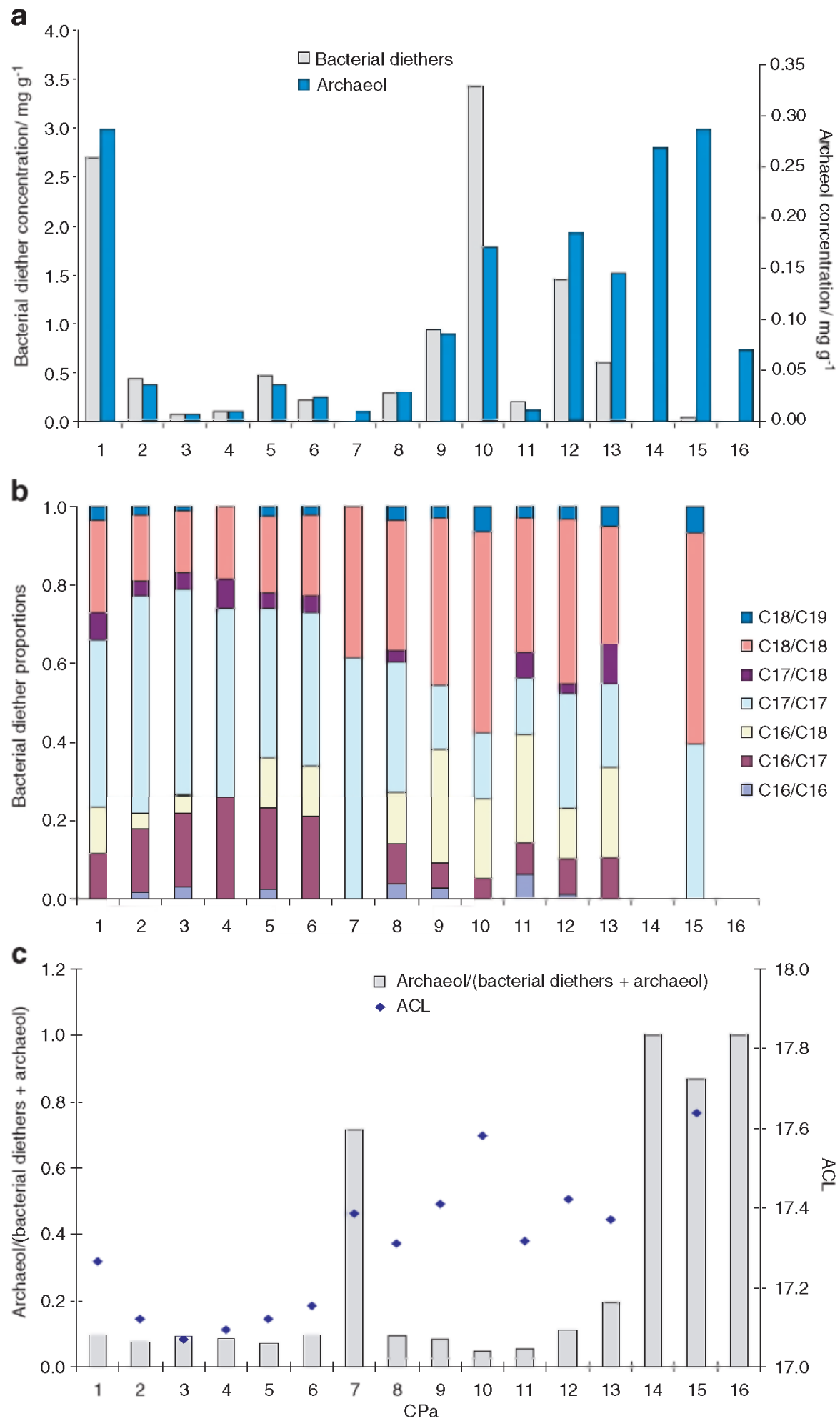

FIG. 3. (a) Total bacterial diether and archaeol concentrations ( $\mathrm{mg} \mathrm{g}^{-1} \mathrm{TOC}$ ); (b) bacterial diether distributions; and (c) ratio of archaeol to bacterial diether abundances (bars) and bacterial diether ACLs (diamonds) in Champagne Pool sinters. Color images available online at www.liebertonline.com/ast

which lacks cyclopentyl moieties, whereas the remaining (and older) sinters have a predominance of components bearing multiple cyclopentyl rings (VIIb-d; Table 4). Consequently, the average number of cyclopentyl rings and the cyclic to acyclic GDGT ratios in CPa1 and CPa5 are lower than those of the older sinters, particularly $\mathrm{CPa} 7$ and $\mathrm{CPa} 16$ (Table 4). Crenarchaeol, comprising a cyclohexyl moiety in addition to four cyclopentyl rings, was also detected in the 
Table 4. Relative Isoprenoid-GDGT Distributions in Champagne Pool Sinters

\begin{tabular}{|c|c|c|c|c|c|c|c|c|c|}
\hline No. of rings & CPa1 & $C P a 5$ & CPa6 & $\mathrm{CPa7}$ & CPa11 & CPa13 & CPa14 & CPa15 & CPa16 \\
\hline 0 & 0.35 & 0.41 & 0.10 & 0.04 & 0.12 & 0.08 & 0.10 & 0.08 & 0.03 \\
\hline 1 & 0.14 & 0.17 & 0.04 & 0.02 & 0.03 & 0.04 & 0.04 & 0.04 & 0.02 \\
\hline 2 & 0.17 & 0.17 & 0.16 & 0.26 & 0.29 & 0.37 & 0.41 & 0.42 & 0.26 \\
\hline 3 & 0.10 & 0.07 & 0.07 & 0.08 & 0.09 & 0.10 & 0.10 & 0.12 & 0.10 \\
\hline 4 & 0.13 & 0.10 & 0.30 & 0.43 & 0.42 & 0.33 & 0.32 & 0.34 & 0.53 \\
\hline 5 & 0.05 & 0.03 & 0.12 & 0.14 & 0.03 & 0.02 & 0.03 & 0.005 & 0.06 \\
\hline 6 & 0.05 & 0.03 & 0.11 & 0.02 & 0.008 & 0.03 & 0.02 & 0.001 & 0.005 \\
\hline 7 & 0.02 & 0.02 & 0.09 & 0.006 & 0.004 & 0.03 & 0.002 & 0.001 & - \\
\hline Cyclic/acyclic ratio & 1.9 & 1.4 & 8.8 & 25.0 & 7.3 & 12.3 & 9.4 & 11.9 & 31.7 \\
\hline Average No. of rings & 2.0 & 1.6 & 3.7 & 3.4 & 2.8 & 2.9 & 2.7 & 2.6 & 3.3 \\
\hline
\end{tabular}

Champagne Pool sinters in considerably lower abundance than the GDGTs discussed above.

In addition to GDGTs comprising isoprenoidal biphytanyl chains, non-isoprenoidal branched GDGTs (VIIe, VIIf) were detected in the three youngest samples analyzed here: CPa1, CPa5, and CPa6. These branched GDGTs are present in subordinate abundance, at least an order of magnitude lower than that recorded for their isoprenoidal counterparts.

\subsection{Free and bound fatty acids}

The free fatty acid fraction consists of a variety of alkanoic acids (Ia; ranging in carbon number $\mathrm{C}_{14}$ to $\mathrm{C}_{32}$ ) and $\beta-\mathrm{OH}$ alkanoic acids (II; $\mathrm{C}_{14}$ to $\mathrm{C}_{20}$ ) (Tables 5 and 6 ). Total fatty acid concentrations are highly variable, ranging from 0.68 (CPa14) to $11.4 \mathrm{mg} \mathrm{g}^{-1}$ TOC (CPa4) (Table 5). These values are comparable to those previously determined for an active sinter from Champagne Pool (Pancost et al., 2006; note that the concentrations in Table 2 of that paper are in $\mu \mathrm{g} \mathrm{g}^{-1}$ rather than $\mathrm{ng} \mathrm{g}^{-1}$ as stated). Here, fatty acids likely derive from multiple sources; lower-molecular-weight fatty acids (i.e., $\mathrm{C}_{14}$ to $\mathrm{C}_{20}$ ) typically derive from bacteria, whereas

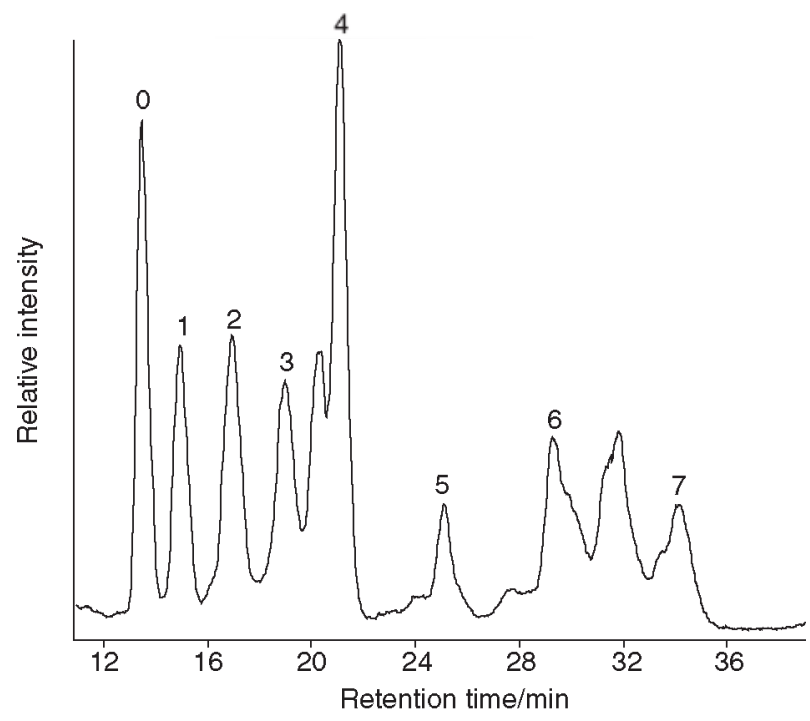

FIG. 4. Partial liquid chromatography/atmospheric pressure chemical ionization-mass spectrometry total ion current chromatogram showing the GDGTs identified in the inactive sinter $\mathrm{CPa} 5$. Numbers denote the total number of cyclopentyl rings in the two biphytanyl chains. higher-molecular-weight components derive from a mixture of plant and bacterial sources. Considering only the fatty acids of inferred bacterial origin (i.e., $\mathrm{C}_{14}$ to $\mathrm{C}_{20}$ ), total concentrations are still variable (ranging from 0.64 to $11 \mathrm{mg} \mathrm{g}^{-1}$ TOC) but are typically higher in the younger sinters, particularly CPa4 and CPa5 (Fig. 5a). The $n-\mathrm{C}_{16: 0}, n-\mathrm{C}_{18: 0}$, and $n-\mathrm{C}_{20: 0}$ alkanoic acids typically predominate, occurring in concentrations at least an order of magnitude larger than those observed for the other fatty acids (Table 5). Still, their relative distributions are highly variable, particularly in the oldest sinters (Fig. 5b). Consequently, fatty acid ACL (defined as the mean carbon chain length calculated from the $\mathrm{C}_{14}$ to $\mathrm{C}_{20}$ fatty acids) is highly variable, particularly in the oldest sinters, ranging from 16.9 (CPa16) to 19.1 (CPa15) (Fig. 5a). Branched and unsaturated components are typically more abundant in the younger sinters $\mathrm{CPa} 5-\mathrm{CPa} 10$, albeit in abundances typically one to two orders of magnitude lower than those of the straight-chain saturated counterparts (Table 5; Fig. 5c). In fact, in CPa 15 and CPa16, branched and unsaturated components were not detected.

In the active and inactive Champagne Pool sinters, $\beta$-OH alkanoic acids are widespread and are present in all but one sample, CPa11 (Table 6; Fig. 6). As with the nonhydroxylated fatty acids, a predominance of $n-\mathrm{C}_{16: 0}, n-\mathrm{C}_{18: 0}$, and $n-\mathrm{C}_{20: 0}$ components was observed, although total abundances are typically an order of magnitude lower than those observed for the nonhydroxylated counterparts (Table 6). The ACL of these hydroxylated fatty acids shows little variation in the younger sinters, $\mathrm{CPa} 1-\mathrm{CPa} 10$; but in the three oldest, $\mathrm{CPa} 14-$ CPa16, the value is significantly lower (Fig. 6).

\subsection{Compounds released by saponification of the putative polar lipid fraction}

The fatty acids released upon saponification of the putative polar lipid fraction are inferred to derive from the hydrolysis of 1,2-diacylglycoglycerolipids and 1,2diacylglycerophospholipids. Caution is required when interpreting this data, particularly absolute abundances, due to the potential loss of phospholipids during analytical workup. Nonetheless, the distribution of the bound fatty acids is similar to that of the free fatty acids, with a general predominance of the $n-\mathrm{C}_{16: 0}, n-\mathrm{C}_{18: 0}$, and $n-\mathrm{C}_{20: 0}$ components. Total abundances are variable in the 16 Champagne Pool sinters, ranging from 0.08 to $12.3 \mathrm{mg} \mathrm{g}^{-1}$, but branched and unsaturated components are generally more abundant in the younger sinters $\mathrm{CPa} 1-\mathrm{CPa} 10$. ACLs of the bound fatty acids exhibit little variation, ranging from 17.0 to 18.6 . 


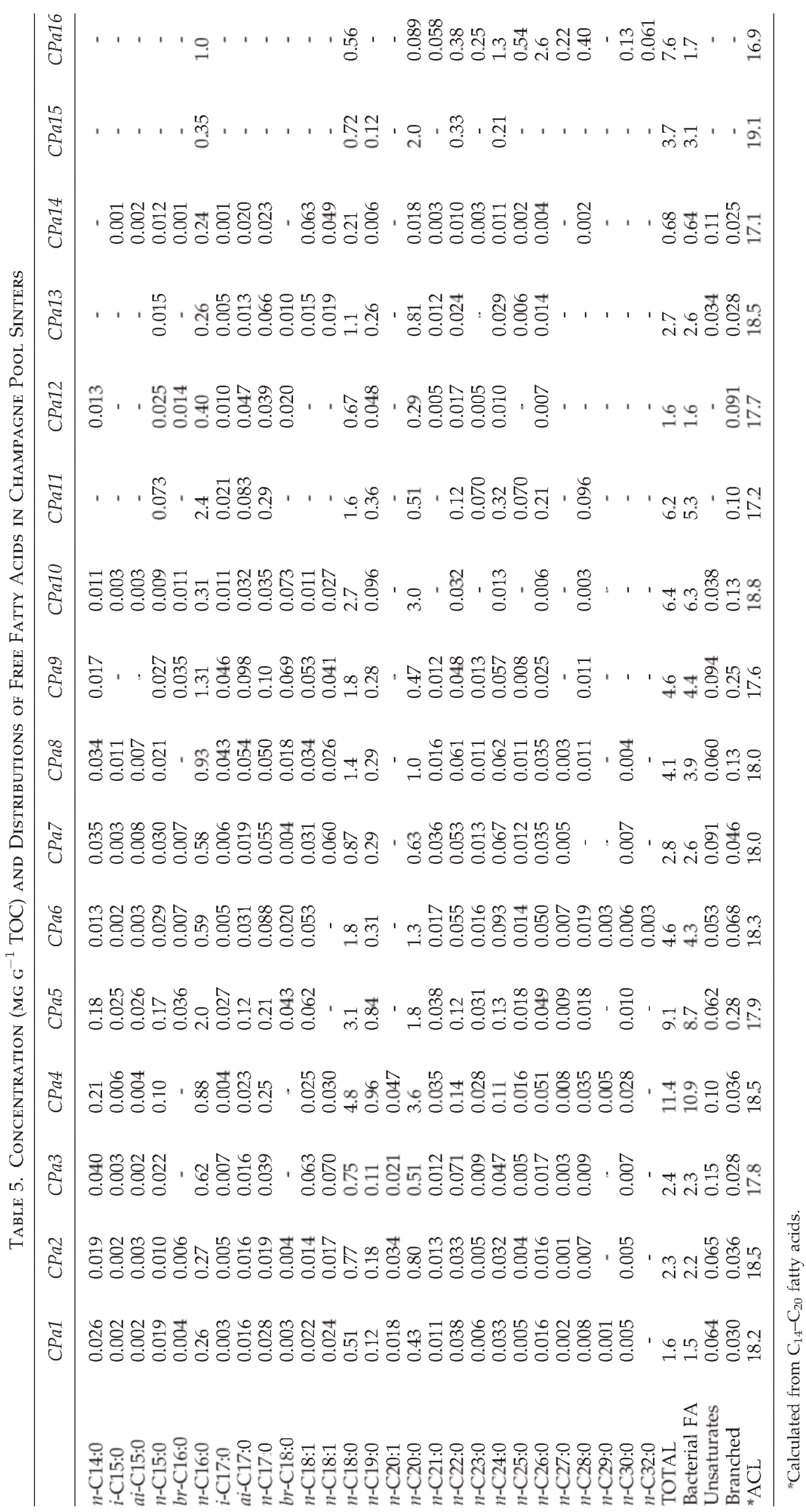




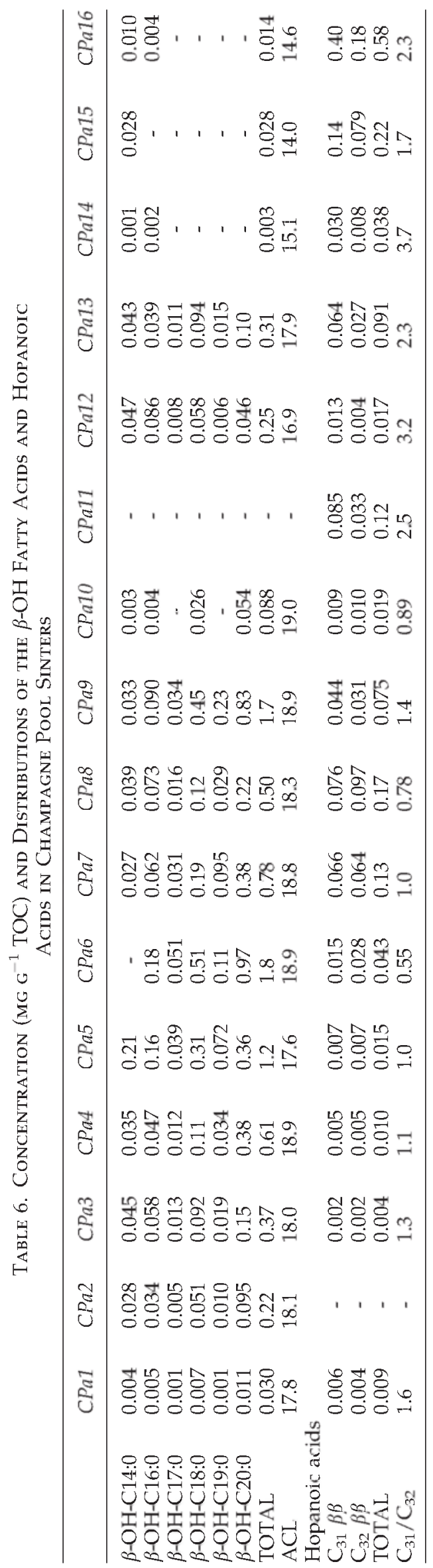

Previously, archaeol and bacterial diether lipids were detected in the saponified polar fraction of a single Champagne Pool sinter (Pancost et al., 2006). In this study, such compounds were also detected in the saponified polar fraction of some sinters, albeit in lower concentrations. Because the methods employed here are not ideal for quantitative preparation of intact polar lipids, abundances should be interpreted with caution; however, as with our previous work there is evidence that intact archaeal and bacterial polar lipids do persist during sinter formation, and examining their structures is the focus of ongoing work.

\subsection{Hopanoic acids}

Hopanoids (III, IV) consist of a pentacyclic triterpenoid structure and are membrane components of a variety of bacteria, including cyanobacteria, methanotrophs, and diverse aerobic heterotrophic bacteria (Rohmer et al., 1984; Farrimond et al., 2000), as well as some anaerobic species (Sinninghe Damsté et al., 2004; Fischer et al., 2005). In the acid fractions, $17 \beta, 21 \beta(\mathrm{H})$ homohopanoic acid $\left(\mathrm{C}_{31}\right)$ and $17 \beta, 21 \beta(\mathrm{H})$ bishomohopanoic acid $\left(\mathrm{C}_{32}\right)$ were detected (Table $6)$, in addition to a range of functionalized bacteriohopanepolyols (Gibson, 2009). The hopanoic acids derive from the oxidative cleavage of vicinal diols in penta- and tetrafunctionalized bacteriohopanoids, respectively (Rohmer et al., 1984; Farrimond et al., 2000). Although previous studies of Champagne Pool sinters have reported the occurrence of various stereoisomers (Pancost et al., 2006), only the biological $17 \beta, 21 \beta(\mathrm{H})$ configuration was detected here. Total concentrations are typically an order of magnitude lower than those of the nonhydroxylated free fatty acids, ranging from $0.004(\mathrm{CPa} 3)$ to $0.58 \mathrm{mg} \mathrm{g}^{-1} \mathrm{TOC}$ (CPa16) (Table 6). While concentrations are invariant in the younger sinters (CPa1$\mathrm{CPa} 6)$, in the older sinters (CPa7-CPa16), concentrations are variable and typically higher (Fig. 7). Furthermore, although concentrations of the $C_{31}$ and $C_{32}$ hopanoic acids are generally similar in the younger sinters, in the older ones (CPa11-CPa16), the $\mathrm{C}_{31}$ component is much more dominant, which is reflected by a much higher $C_{31} / C_{32}$ ratio (Fig. 7) and implies a higher proportion of pentafunctionalized bacteriohopanoids.

\section{Discussion}

Central to our evaluation of the fidelity of lipid biomarker signatures is an assessment of both lipid incorporation during sinter precipitation and their subsequent preservation. In our companion paper (Kaur et al., 2011), we evaluated the likely sources of the microbial lipids identified in the Champagne Pool active sinters by comparison with previous molecular analyses of the spring as well as known sources of different lipid classes; that work complements earlier papers that were also focused on profiling lipid signatures in a variety of $\mathrm{New}$ Zealand geothermal systems (Pancost et al., 2005, 2006). Here, we focus on the temporal variations in lipid concentrations and distributions and interpret these in terms of preservation as well as spring chemistry and microbiology.

\subsection{Sources of lipids}

The lipid biomarkers observed in the inactive Champagne Pool sinters are generally similar to those reported in the 

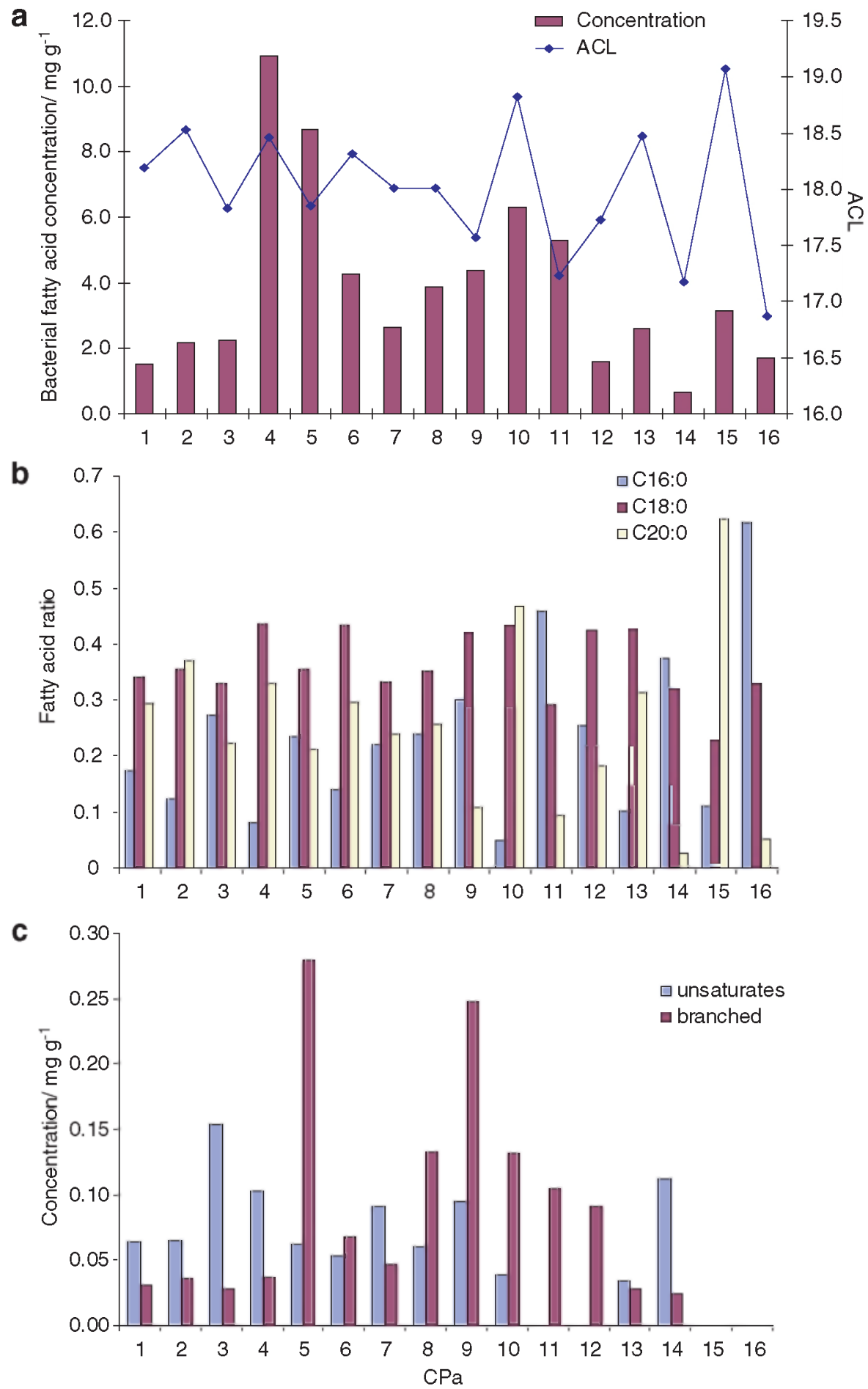

FIG. 5. (a) Bacterial fatty acid (defined as all $\mathrm{C}_{14}$ to $\mathrm{C}_{20}$ fatty acids) concentrations ( $\mathrm{mg}^{-1} \mathrm{TOC}$ ) and $\mathrm{ACL}$; (b) proportions of the $\mathrm{C}_{16: 0}, \mathrm{C}_{18: 0}$, and $\mathrm{C}_{20: 0}$ fatty acids relative to the total bacterial fatty acids; and (c) concentrations of the branched and unsaturated components ( $\mathrm{mg} \mathrm{g}^{-1} \mathrm{TOC}$ ) in Champagne Pool sinters. Color images available online at www.liebertonline.com/ast

active ones and likely derive from the same bacterial, archaeal, and in some cases allochthonous sources. In our study of the active spicular sinters (Kaur et al., 2011), bacterial non-isoprenoidal diethers were ascribed to a Thermodesulfobacteriales and Aquificales source, which is consistent with DNA analyses of Champagne Pool sinters and wa- ters (Hetzer et al., 2007; Childs et al., 2008); archaeol and isoprenoid-GDGTs were ascribed to Sulfolobales or Thermofilum-like populations, or both (Hetzer et al., 2007); lower-molecular-weight fatty acids were attributed to a range of potential sources; branched fatty acids were attributed to Thermodesulfobacteriales (Langworthy et al., 1983); and 


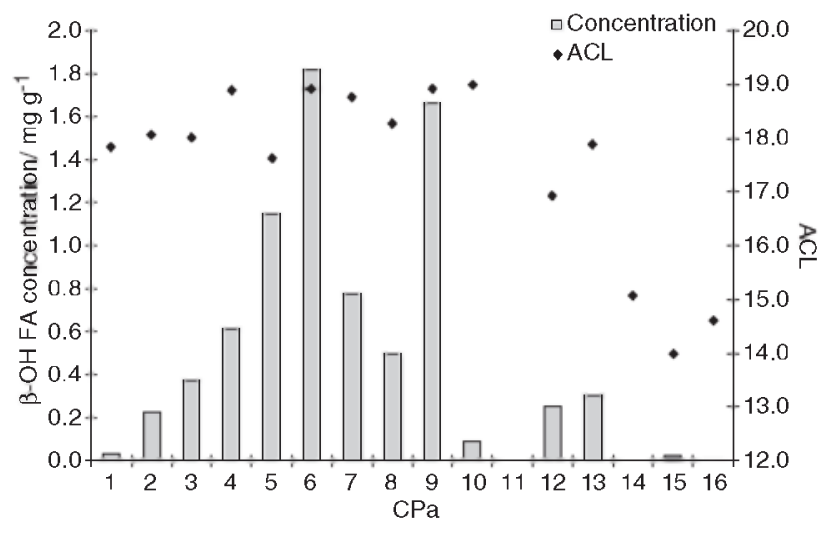

FIG. 6. $\quad \beta-\mathrm{OH}$ fatty acid concentrations ( $\left.\mathrm{mg} \mathrm{g}^{-1} \mathrm{TOC}\right)$ and $\mathrm{ACL}$ in Champagne Pool sinters.

hopanoic acids, degradation products of bacteriohopanoids, were ascribed to an unknown group of bacteria distinct from Aquificales and Thermodesulfobacteriales, as these organisms are not known to synthesize hopanoids. Note that other biomarkers for Aquificales, such as monoethers (Jahnke et al., 2001), were not detected, which perhaps suggests that Thermodesulfobacteriales are the primary source of the bacterial diethers or, alternatively, that the Aquificales species in this setting do not synthesize monoether lipids. The source of the branched GDGTs remains unresolved; possibly they derive from thermophilic bacteria indigenous to the hot spring (Sinninghe Damsté et al., 2007) or an allochthonous source, including bacteria living in surrounding geothermally heated soils (Schouten et al., 2007) or mesophilic anaerobic bacteria (Weijers et al., 2006). Since these assignments are partially based on phylogenetic analyses of active Champagne Pool facies (Hetzer et al., 2007; Childs et al., 2008), caution is required when interpreting the sources of lipid biomarkers in inactive materials. However, many of the main characteristics of the active sinter biomarker distributions-including the presence of $\mathrm{C}_{16}, \mathrm{C}_{18}$, and $\mathrm{C}_{20}$ fatty acids; non-isoprenoidal diethers, hopanoids, archaeal diethers and GDGTs; and the absence of monoethers and cyanobacterial or Chloroflexus

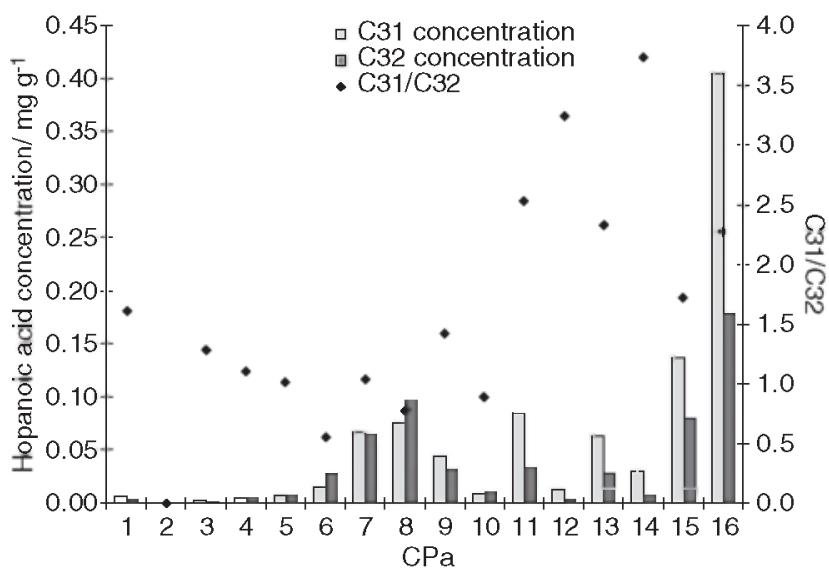

FIG. 7. Concentrations of the $17 \beta, 21 \beta(\mathrm{H})$ homohopanoic acid $\left(\mathrm{C}_{31}\right)$ and $17 \beta, 21 \beta(\mathrm{H})$ bishomohopanoic acid $\left(\mathrm{C}_{32}\right)$, and $\mathrm{C}_{31} / \mathrm{C}_{32}$ ratios in Champagne Pool sinters. biomarkers (e.g., Shiea et al., 1991; van der Meer et al., 2002)_are also characteristic of the inactive sinters.

4.1.1. Interpretation of microbial community structure: fidelity of lipid biomarkers. In all four active sinters, the same principal biomarker classes are present, which represent a range of sources largely consistent with recent DNA analyses (Hetzer et al., 2007; Childs et al., 2008). Biomarker concentrations do vary among the active sinters; these are dependent on a wide range of factors but most likely reflect the rates and mechanisms of sinter formation and consequential impacts on the amount of biomass encapsulated. However, biomarker distributions are largely conserved within a given class: bacterial diether distributions, the bacterial diether to archaeol ratio, diether ACL, fatty acid distributions (hydroxylated and nonhydroxylated), fatty acid ACL (hydroxylated and nonhydroxylated), and hopanoic acid distributions are all relatively invariant in the active sinters. Thus, for a given compound class (reflecting a narrow range of organisms), little variation is observed. This suggests that these compound classes derive from similar microbial populations, and the fact that this is recorded by lipid biomarkers suggests that the biomarker composition of precipitated sinters does indeed record microbial populations with some fidelity (Kaur et al., 2011).

\subsection{Lipid preservation}

Concentrations of lipid biomarkers are typically highly variable; more importantly, concentrations mostly show no correlation with sinter age. In fact, of the compounds investigated, only unsaturated fatty acids and $\beta-\mathrm{OH}$ fatty acids are significantly less abundant in the oldest sinters than in the active and young inactive sinters. For all other compounds, concentration variations between young and old sinters are typically comparable to those that occur among the four active sinters themselves. This suggests that lipids are preserved once the sinter is formed, and biomarker concentrations are largely governed by the size of the microbial population and how well it is preserved during sinter precipitation.

The presence of highly functionalized compounds, for example, putative glycolipids and phospholipids (with distributions similar to their free fatty acid counterparts), in the inactive sinters also suggests that silicification facilitates geochemical preservation. Further evidence comes from the perseverance of lipid distribution patterns. Geothermal lipids are preserved even in highly weathered sinters, which suggests that these signatures can persist for extended periods of time.

4.2.1. Past changes in biomarker distributions. Although the predominant biomarker classes occur in all Champagne Pool sinters, there are clear differences in the lipid distributions from which past changes in microbiology can be inferred. Some of these could reflect a homeoviscous adaptation of the same microbial assemblage to differences in $\mathrm{pH}$ or temperature. Environmental conditions can exert a direct influence on lipid biosynthesis, with some organisms able to adjust membrane lipid composition to maintain membrane integrity at extremes of temperature and $\mathrm{pH}$ (e.g., Gliozzi et al., 1983; Zeng et al., 1992; Rothschild and Mancinelli, 2001; 
Schouten et al., 2007). At high temperatures, membrane lipids that are more stable or yield more thermally stable membranes become more abundant (e.g., Zeng et al., 1992; Beney and Gervais, 2001; Schouten et al., 2007) in order to maintain optimal membrane fluidity (i.e., homeoviscous adaptation; Sinensky, 1974; Hazel, 1995) or proton permeability (Albers et al., 2000), or both. Similarly, at low $\mathrm{pH}$ levels, acidophiles modify their lipid composition to maintain a high $\mathrm{pH}$ gradient across the cell membrane (Albers et al., 2000; Arakawa et al., 2001; Macalady et al., 2004). Alternatively or additionally, differences in lipid distributions can reflect changes in the microbial community structure.

Changes in microbial assemblage are likely to exert the dominant control on changes in the relative amounts of different compound classes. For example, the high abundance of archaeol, particularly relative to the bacterial diethers, in the oldest sinters (Fig. 3) suggests a different microbial assemblage in the past. This is unlikely to reflect differential preservation of microbial lipids, since bacterial and archaeal diether lipids of similar chemical structure and presumably similar preservation potential are being compared. Instead, the distribution trends here appear to reflect different microbial assemblages and, by extension, a different geothermal environment in the past. Since archaea tend to predominate at higher temperatures and lower $\mathrm{pH}$ (e.g., Robertson et al., 2005), high archaeol abundances suggest hotter geothermal temperatures or lower $\mathrm{pH}$ conditions at Champagne Pool in the past. This is consistent with previous studies that demonstrate a decrease in spring temperature on spring demise (Brock, 1978).

In contrast, changes in hopanoid distributions could either reflect homeoviscous adaptation or differences in microbial community structure. Homohopanoic acid $\left(\mathrm{C}_{31}\right)$ and bishomohopanoic acid $\left(\mathrm{C}_{32}\right)$ derive from the oxidative cleavage of vicinal diols in penta- and tetrafunctionalized bacteriohopanoids, respectively (Rohmer et al., 1984; Farrimond et al., 2000), and their distributions vary among different bacterial groups (Talbot and Farrimond, 2007; Talbot et al., 2008). In the Champagne Pool sinters, the abundance of $C_{31}$ homohopanoic acid relative to $\mathrm{C}_{32}$ bishomohopanoic acid is much higher in the oldest sinters (Fig. 7). This is consistent with intact bacteriohopanoid analyses (Gibson, 2009), which revealed several novel pentafunctionalized bacteriohopanpolyols in the oldest sinters. Although the source of these hopanoids is unclear, this could reflect a change in community composition in the past. Alternatively, several studies have demonstrated changes in hopanoid content and distributions in bacteria under different growth conditions. Total hopanoid content increases with increasing growth temperature in the thermoacidophilic bacterium Alicyclobacillus acidocaldarius (Poralla et al., 1984), the ethanologenic Zymomonas mobilis (Schmidt et al., 1986), and an acetic acid bacterium Frateuria aurantia (Joyeux et al., 2004). Since hopanoids are thought to regulate membrane fluidity and induce order in the phospholipid membrane (Kannenberg and Poralla, 1999), an increase in hopanoid abundances at higher temperatures is not surprising. Joyeux et al. (2004) also reported the biosynthesis of pentafunctionalized hopanoids in response to heat stress in Frateuria aurantia. Here, higher hopanoic acid concentrations and elevated $\mathrm{C}_{31} / \mathrm{C}_{32}$ hopanoic acid ratios in the older sinters could therefore reflect either homeoviscous adaptations or a different microbial assem- blage in response to higher geothermal temperatures in the past.

Other differences between young and old biomarker distributions could arise solely from homeoviscous adaptation. The proportions of GDGTs comprising multiple cyclopentyl rings are much higher in the oldest samples (Table 4). At high temperatures and low $\mathrm{pH}$, thermophilic archaea tend to biosynthesize more GDGTs relative to diethers and a greater proportion of GDGTs with cyclopentyl moieties (Gliozzi et al., 1983; DeRosa et al., 1986), since these components stabilize the cell membrane, maintaining optimal membrane fluidity and a viable proton motive force (Albers et al., 2000). Thus, the higher proportion of GDGTs bearing cyclopentyl moieties in the oldest samples could reflect an archaeal adaptation to higher temperatures, lower $\mathrm{pH}$ levels, or a combination of both.

Similarly, the distributions of fatty acids are also affected by environmental conditions. Thermophilic bacteria respond to high temperatures by increasing their average fatty acid chain length (Weerkamp and Heinen, 1972; Oshima and Miyagawa, 1974; Russell, 1984) and decreasing the degree of unsaturation and degree of branching (Ray et al., 1971; Kaneda, 1991; Zeng et al., 1992). The fatty acid ACLs in the Champagne Pool sinters are higher than those typically observed in mesophilic environments (e.g., Zelles, 1999), which is consistent with a high-temperature environment. Within the sinters, fatty acid distributions are highly variable (Fig. 5). Nonetheless, the lack of branched and unsaturated fatty acids in the oldest sinters is consistent with a higher temperature at Champagne Pool in the past. In contrast, the ACL of the free and bound fatty acids shows no trend with sinter age, with older sinters exhibiting both the highest and lowest ACLs of the entire sample suite. This possibly reflects the complex and multiple sources of these compounds, including a range of microbial but also allochthonous sources; if so, the low ACLs could arise from soil bacterial inputs, and the higher ACLs (due to high abundances of the $C_{20}$ fatty acid) may reflect elevated past temperatures.

Analogous to the behavior of acyl membrane lipids, it is possible that the average alkyl chain length of bacterial diether lipids will also increase with higher temperatures (Jahnke et al., 2001; Pancost et al., 2005), although this has not yet been directly studied. Here, we observed an increase in bacterial diether ACL with sinter age (Fig. 3c), highlighted by the dominance of the $\mathrm{C}_{18} / \mathrm{C}_{18}$ component in the older sinters. If these changes are indeed a result of homeoviscous adaptation, they are further evidence of hotter temperatures at Champagne Pool in the past. Such adaptive responses have not been previously reported and potentially represent new insight into survival strategies in extremes.

\section{Conclusions}

Biomarker analyses of the active and inactive sinters from Champagne Pool revealed excellent preservation of lipid biomarkers once the sinter has formed. Indeed, variations in lipid concentration between active and inactive sinters are comparable to those that occur among the active sinters themselves. Furthermore, the presence of highly functionalized compounds in the inactive sinters suggests excellent preservation. These findings suggest that silicification facilitates geochemical preservation, and once encased in the mineral 
matrix, these lipids can persist for extended periods of time, even after significant weathering. Consequently, they can be used to profile past microbiological and environmental conditions. Here, the predominance of generally similar biomarker groups in all sinters suggests a similar microbial community in Champagne Pool throughout its history. However, subtle differences in the lipid distributions between the younger and older sinters provide evidence for different environmental and microbiological conditions in the past. The increase in archaeol concentrations relative to the bacterial diethers in the older sinters suggests a somewhat different past microbial assemblage, perhaps due to higher temperatures or lower $\mathrm{pH}$ (Robertson et al., 2005), shortly after the formation of Champagne Pool. Further evidence of higher spring temperatures in the past includes changes in lipid distributions that could reflect homeoviscous adaptations: the high proportion of cyclic GDGTs, the high ACL of the bacterial diethers, and the high concentrations of the hopanoic acids, particularly the $\mathrm{C}_{31}$ component. Clearly, further work is necessary, but this study demonstrates that lipid biomarkers are well preserved in geothermal settings, which reinforces their potential as tracers for past life in such environments.

\section{Acknowledgments}

We thank R. Berstan and I. Bull of the Organic Geochemistry Unit and the Bristol Node of the NERC Life Sciences Mass Spectrometry Facility for analytical support, M. Hall for sample preparation, and R. Gibson and H. Talbot of Newcastle University for very useful feedback on this ongoing collaboration. We also acknowledge The Leverhulme Trust for funding assistance, the Geological Society for funding fieldwork, the EPSRC for supporting G. Kaur's Ph.D. studentship, and the Royal Society of New Zealand for providing an ISAT Grant to B.M., facilitating the collaboration.

\section{Author Disclosure Statement}

No competing financial interests exist.

\section{Abbreviations}

ACL, average chain length; DCM, dichloromethane; GDGTs, glycerol dialkyl glycerol tetraethers; $\mathrm{MeOH}$, methanol; TOC, total organic carbon; TVZ, Taupo Volcanic Zone.

\section{References}

Albers, S.V., van de Vossenberg, J., Driessen, A.J.M., and Konings, W.N. (2000) Adaptations of the archaeal cell membrane to heat stress. Front Biosci 5:D813-D820.

Arakawa, K., Eguchi, T., and Kakinuma, K. (2001) 36-Membered macrocyclic diether lipid is advantageous for archaea to thrive under the extreme thermal environments. Bull Chem Soc Jpn 74:347-356.

Beney, L. and Gervais, P. (2001) Influence of the fluidity of the membrane on the response of microorganisms to environmental stresses. Appl Microbiol Biotechnol 57:34-42.

Birgel, D., Thiel, V., Hinrichs, K.U., Elvert, M., Campbell, K.A., Reitner, J., Farmer, J.D., and Peckmann, J. (2006) Lipid biomarker patterns of methane-seep microbialites from the
Mesozoic convergent margin of California. Org Geochem 37: 1289-1302.

Blank, C.E., Cady, S.L., and Pace, N.R. (2002) Microbial composition of near-boiling silica-depositing thermal springs throughout Yellowstone National Park. Appl Environ Microbiol 68:5123-5135.

Brock, T.D. (1978) Thermophilic Microorganisms and Life at High Temperatures, Springer-Verlag, New York.

Brocks, J.J., Love, G.D., Summons, R.E., Knoll, A.H., Logan, G.A., and Bowden, S.A. (2005) Biomarker evidence for green and purple sulphur bacteria in a stratified Palaeoproterozoic sea. Nature 437:866-870.

Childs, A., Mountain, B., O'Toole, R., and Stott, M. (2008) Relating microbial community and physicochemical parameters of a hot spring: Champagne Pool, Wai-o-tapu, New Zealand. Geomicrobiol J 25:441-453.

Cockell, C., Bridges, J., Dannatt, L., Burchell, M., Patel, M., and Danson, M. (2009) Where to land on Mars. Astronomy and Geophysics 50:18-26.

DeRosa, M. and Gambacorta, A. (1988) The lipids of archaebacteria. Prog Lipid Res 27:153-175.

DeRosa, M., Gambacorta, A., and Gliozzi, A. (1986) Structure, biosynthesis, and physicochemical properties of archaebacterial lipids. Microbiol Rev 50:70-80.

Des Marais, D.J., Nuth, J.A., Allamandola, L.J., Boss, A.P., Farmer, J.D., Hoehler, T.M., Jakosky, B.M., Meadows, V.S., Pohorille, A., and Runnegar, B. (2008) The NASA Astrobiology Roadmap. Astrobiology 8:715-730.

Eglinton, G., Gonzalez, A.G., Hamilton, R.J., and Raphael, R.J. (1962) Hydrocarbon constituents of the wax coatings of plant leaves: a taxonomic survey. Phytochemistry 1:89-102.

Farrimond, P., Head, I.M., and Innes, H.E. (2000) Environmental influence on the biohopanoid composition of recent sediments. Geochim Cosmochim Acta 64:2985-2992.

Fischer, W.W., Summons, R.E., and Pearson, A. (2005) Targeted genomic detection of biosynthetic pathways: anaerobic production of hopanoid biomarkers by a common sedimentary microbe. Geobiology 3:33-40.

Freeman, K.H. (2001) Isotopic biogeochemistry of marine organic carbon. Reviews in Mineralogy and Geochemistry 43:579606.

Gibson, R.A. (2009) The distribution of bacteriohopanepolyols in terrestrial geothermal ecosystems. Ph.D. Thesis, Newcastle University, Newcastle upon Tyne, UK.

Gibson, R.A., Talbot, H.M., Kaur, G., Pancost, R.D., and Mountain, B. (2008) Bacteriohopanepolyol signatures of cyanobacterial and methanotrophic bacterial populations recorded in a geothermal vent sinter. Org Geochem 39:1020-1023.

Gliozzi, A., Paoli, G., De Rosa, M., and Gambacorta, A. (1983) Effect of isoprenoid cyclization on the transition temperature of lipids in thermophilic archaebacteria. Biochim Biophys Acta $735: 234-242$.

Guidry, S.A. and Chafetz, H.S. (2003) Siliceous shrubs in hot springs from Yellowstone National Park, Wyoming, U.S.A. Can J Earth Sci 40:1571-1583.

Hayes, J.M. (2001) Fractionation of carbon and hydrogen isotopes in biosynthetic processes. Reviews in Mineralogy and Geochemistry 43:225-278.

Hazel, J.R. (1995) Thermal adaptations in biological membranes: is homeoviscous adaptation the explanation? Annu Rev Physiol 57:19-42.

Hetzer, A., Morgan, H.W., McDonald, I.R., and Daughney, C.J. (2007) Microbial life in Champagne Pool, a geothermal spring in Waiotapu, New Zealand. Extremophiles 11:605-614. 
Hopmans, E.C., Schouten, S., Pancost, R.D., van der Meer, M.T.J., and Sinninghe Damsté, J.S. (2000) Analysis of intact tetraether lipids in archaeal cell material and sediments by high performance liquid chromatography/atmospheric pressure chemical ionization mass spectrometry. Rapid Commun Mass Spectrom 14:585-589.

Houghton, B.F., Wilson, C.J.N., McWilliams, M.O., Lanphere, M.A., Weaver, S.D., Briggs, R.M., and Pringle, M.S. (1995) Chronology and dynamics of a large silicic magmatic system-Central Taupo Volcanic Zone, New Zealand. Geology 23:13-16.

Huber, R., Wilharm, T., Huber, D., Trincone, A., Burggraf, S., Konig, H., Rachel, R., Rockinger, I., Fricke, H., and Stetter, K.O. (1992) Aquifex pyrophilus gen. nov. sp. nov. represents a novel group of marine hyperthermophilic hydrogen-oxidizing bacteria. Syst Appl Microbiol 15:340-351.

Huber, R., Rossnagel, P., Woese, C.R., Rachel, R., Langworthy, T.A., and Stetter, K.O. (1996) Formation of ammonium from nitrate during chemolithoautotrophic growth of the extremely thermophilic bacterium Ammonifex degensii gen. nov. sp. nov. Syst Appl Microbiol 19:40-49.

Jahnke, L.L., Eder, W., Huber, R., Hope, J.M., Hinrichs, K.U., Hayes, J.M., Marais, D.J.D., Cady, S.L., and Summons, R.E (2001) Signature lipids and stable carbon isotope analyses of Octopus Spring hyperthermophilic communities compared with those of Aquificales representatives. Appl Environ Microbiol 67:5179-5189.

Jones, B., Renaut, R.W., and Rosen, M.R. (1997) Biogenicity of silica precipitation around geysers and hot-spring vents, North Island, New Zealand. J Sediment Res A Sediment Petrol Process 67:88-104.

Jones, B., Renaut, R.W., and Rosen, M.R. (2001) Biogenicity of gold- and silver-bearing siliceous sinters forming in hot $\left(75^{\circ} \mathrm{C}\right)$ anaerobic spring-waters of Champagne Pool, Waiotapu, North Island, New Zealand. J Geol Soc London 158:895-912.

Joyeux, C., Fouchard, S., Llopiz, P., and Neunlist, S. (2004) Influence of the temperature and the growth phase on the hopanoids and fatty acids content of Frateuria aurantia (DSMZ 6220). FEMS Microbiol Ecol 47:371-379.

Kaneda, T. (1991) Iso- and anteiso-fatty acids in bacteria: biosynthesis, function, and taxonomic significance. Microbiol Rev 55:288-302.

Kannenberg, E.L. and Poralla, K. (1999) Hopanoid biosynthesis and function in bacteria. Naturwissenschaften 86:168-176.

Kaur, G., Mountain, B.W., and Pancost, R.D. (2008) Microbial membrane lipids in active and inactive sinters from Champagne Pool, New Zealand: elucidating past geothermal chemistry and microbiology. Org Geochem 39:1024-1028.

Kaur, G., Mountain, B.W., Hopmans, E.C., and Pancost, R.D. (2011) Relationship between lipid distribution and geochemical environment within Champagne Pool, Waiotapu, New Zealand. Org Geochem, in press.

Konhauser, K.O., Phoenix, V.R., Bottrell, S.H., Adams, D.G., and Head, I.M. (2001) Microbial-silica interactions in Icelandic hot spring sinter: possible analogues for some Precambrian siliceous stromatolites. Sedimentology 48:415-434.

Langworthy, T.A., Holzer, G., Zeikus, J.G., and Tornabene, T.G. (1983) Iso-branched and anteiso-branched glycerol diethers of the thermophilic anaerobe Thermodesulfotobacterium-Commune. Syst Appl Microbiol 4:1-17.

Lloyd, E.F. (1959) The hot springs and hydrothermal eruptions of Waiotapu. New Zealand Journal of Geology and Geophysics 2:141-176.
Macalady, J.L., Vestling, M.M., Baumler, D., Boekelheide, N., Kaspar, C.W., and Banfield, J.F. (2004) Tetraether-linked membrane monolayers in Ferroplasma spp: a key to survival in acid. Extremophiles 8:411-420.

Mountain, B.W., Benning, L.G., and Boerema, J.A. (2003) Experimental studies on New Zealand hot spring sinters: rates of growth and textural development. Can J Earth Sci 40:16431667.

Oshima, M. and Miyagawa, A. (1974) Comparative studies on the fatty acid composition of moderately and extremely thermophilic bacteria. Lipids 9:476-480.

Pancost, R.D., Bouloubassi, I., Aloisi, G., and Damsté, J.S.S. (2001) Three series of non-isoprenoidal dialkyl glycerol diethers in cold-seep carbonate crusts. Org Geochem 32:695-707.

Pancost, R.D., Pressley, S., Coleman, J.M., Benning, L.G., and Mountain, B.W. (2005) Lipid biomolecules in silica sinters: indicators of microbial biodiversity. Environ Microbiol 7:66-77.

Pancost, R.D., Pressley, S., Coleman, J.M., Talbot, H.M., Kelly, S.P., Farrimond, P., Schouten, S., Benning, L., and Mountain, B.W. (2006) Composition and implications of diverse lipids in New Zealand geothermal sinters. Geobiology 4:71-92.

Pearson, A., Huang, Z., Ingalls, A.E., Romanek, C.S., Wiegel, J., Freeman, K.H., Smittenberg, R.H., and Zhang, C.L. (2004) Nonmarine crenarchaeol in Nevada hot springs. Appl Environ Microbiol 70:5229-5237.

Peckmann, J. and Thiel, V. (2004) Carbon cycling at ancient methane-seeps. Chem Geol 205:443-467.

Phoenix, V.R., Renaut, R.W., Jones, B., and Ferris, F.G. (2005) Bacterial S-layer preservation and rare arsenic-antimonysulphide bioimmobilization in siliceous sediments from Champagne Pool hot spring, Waiotapu, New Zealand. J Geol Soc London 162:323-332.

Poralla, K., Hartner, T., and Kannenberg, E. (1984) Effect of temperature and $\mathrm{pH}$ on the hopanoid content of Bacillus acidocaldarius. FEMS Microbiol Lett 23:253-256.

Ray, P.H., White, D.C., and Brock, T.D. (1971) Effect of temperature on the fatty acid composition of Thermus aquaticus. J Bacteriol 106:25-30.

Ring, M.W., Schwar, G., Thiel, V., Dickschat, J.S., Kroppenstedt, R.M., Schulz, S., and Bode, H.B. (2006) Novel iso-branched ether lipids as specific markers of developmental sporulation in the Myxobacterium Myxococcus xanthus. I Biol Chem 281:36691-36700.

Robertson, C.E., Harris, J.K., Spear, J.R., and Pace, N.R. (2005) Phylogenetic diversity and ecology of environmental archaea. Curr Opin Microbiol 8:638-642.

Rohmer, M., Bouviernave, P., and Ourisson, G. (1984) Distribution of hopanoid triterpenes in prokaryotes. I Gen Microbiol 130:1137-1150.

Rothschild, L.J. and Mancinelli, R.L. (2001) Life in extreme environments. Nature 409:1092-1101.

Russell, N.J. (1984) Mechanisms of thermal adaptation in bacteria-blueprints for survival. Trends Biochem Sci 9:108-112.

Schmidt, A., Bringer-Meyer, B., Poralla, K., and Sahm, H. (1986) Effect of alcohols and temperature on the hopanoid content of Zymomonas mobilis. Appl Microbiol Biotechnol 25:32-36.

Schouten, S., van der Meer, M.T.J., Hopmans, E.C., Rijpstra, W.I.C., Reysenbach, A.L., Ward, D.M., and Sinninghe Damsté, J.S. (2007) Archaeal and bacterial glycerol dialkyl glycerol tetraether lipids in hot springs of Yellowstone National Park. Appl Environ Microbiol 73:6181-6191.

Schultzelam, S., Ferris, F.G., Konhauser, K.O., and Wiese, R.G. (1995) In situ silicification of an Icelandic hot spring microbial 
mat: implications for microfossil formation. Can J Earth Sci 32:2021-2026.

Shiea, J., Brassell, S.C., and Ward, D.M. (1990) Mid-chain branched monomethyl and dimethyl alkanes in hot-spring cyanobacterial mats: a direct biogenic source for branched alkanes in ancient sediments. Org Geochem 15:223-231.

Shiea, J., Brassell S.C., and Ward, D.M. (1991) Comparative analysis of extractable lipids in hot spring microbial mats and their component photosynthetic bacteria. Org Geochem 17:309-319.

Simoneit, B.R.T. (2002) Molecular indicators (biomarkers) of past life. Anat Rec 268:186-195.

Sinensky, M. (1974) Homeoviscous adaptation-a homeostatic process that regulates the viscosity of membrane lipids in Escherichia coli. Proc Natl Acad Sci USA 71:522-525.

Sinninghe Damsté, J.S., Rijpstra, W.I., Schouten, S., Fuerst, J.A., Jetten, M.S., and Strous, M. (2004) The occurrence of hopanoids in planctomycetes: implications for the sedimentary biomarker record. Org Geochem 35:561-566.

Sinninghe Damsté, J.S., Rijpstra, W.I., Geenevasen, J.A.J., Strous, M., and Jetten, M.S.M. (2005) Structural identification of ladderane and other membrane lipids of planctomycetes capable of anaerobic ammonium oxidation (anammox). FEBS 272:4270-4283.

Sinninghe Damsté, J.S., Rijpstra, W.I., Hopmans, E.C., Schouten, S., Balk, M., and Stams, A.J. (2007) Structural characterization of diabolic acid-based tetraester, tetraether and mixed ether/ ester, membrane-spanning lipids of bacteria from the order Thermotogales. Arch Microbiol 188:629-641

Summons, R.E., Jahnke, L.L., and Simoneit, B.R.T. (1996) Lipid biomarkers for bacterial ecosystems: studies of cultured organisms, hydrothermal environments and ancient sediments. In Evolution of Hydrothermal Ecosystems on Earth (and Mars?), Ciba Foundation Symposium 202, edited by G.R. Bock and J.A. Goode, John Wiley and Sons, Chichester, UK, pp 174-194. Summons, R.E., Bradley, A.S., Jahnke, L.L., and Waldbauer, J.R. (2006) Steroids, triterpenoids and molecular oxygen. Philos Trans $R$ Soc Lond B Biol Sci 361:951-968.

Talbot, H.M. and Farrimond, P. (2007) Bacterial populations recorded in diverse sedimentary biohopanoid distributions. Org Geochem 38:1212-1225.

Talbot, H.M., Farrimond, P., Schaeffer, P., and Pancost, R.D. (2005) Bacteriohopanepolyols in hydrothermal vent biogenic silicates. Org Geochem 36:663-672.

Talbot, H.M., Summons, R.E., Jahnke, L.L., Cockell, C.S., Rohmer, M., and Farrimond, P. (2008) Cyanobacterial bacteriohopanepolyol signatures from cultures and natural environmental settings. Org Geochem 39:232-263.

Thiel, V., Peckmann, J., Richnow, H.H., Luth, U., Reitner, J., and Michaelis, W. (2001) Molecular signals for anaerobic methane oxidation in Black Sea seep carbonates and a microbial mat. Mar Chem 73:97-112.

van der Meer, M.T.J., Schouten, S., de Leeuw, J.W., and Ward, D.M. (2000) Autotrophy of green non-sulphur bacteria in hot spring microbial mats: biological explanations for isotopically heavy organic carbon in the geological record. Environ $\mathrm{Mi}$ crobiol 2:428-435.

van der Meer, M.T., Schouten, S., Hanada, S., Hopmans, E.C., Damsté, J.S., and Ward, D.M. (2002) Alkane-1,2-diol-based glycosides and fatty glycosides and wax esters in Roseiflexus castenholzii and hot spring microbial mats. Arch Microbiol 178:229-237.

Ward, D.M., Brassell S.C., and Eglinton, G. (1985) Archaebacterial lipids in hot spring microbial mats. Nature 318:656-659.

Weerkamp, A. and Heinen, W. (1972) Effect of temperature on the fatty acid composition of the extreme thermophiles, Bacillus caldolyticus and Bacillus caldotenax. J Bacteriol 109:443-446.

Weijers, J.W., Schouten, S., Hopmans, E.C., Geenevasen, J.A., David, O.R., Coleman, J.M., Pancost, R.D., and Sinninghe Damsté, J.S. (2006) Membrane lipids of mesophilic anaerobic bacteria thriving in peats have typical archaeal traits. Environ Microbiol 8:648-657.

Zelles, L. (1999) Fatty acid patterns of phospholipids and lipopolysaccarides in the characterisation of microbial communities in soil: a review. Biol Fertil Soils 29:111-129.

Zeng, Y.B., Ward, D.M., Brassell, S.C., and Eglinton, G. (1992) Biogeochemistry of hot-spring environments: 2. Lipid compositions of Yellowstone (Wyoming, USA) cyanobacterial and Chloroflexus mats. Chem Geol 95:327-345.

Zhang, C.L., Pearson, A., Li, Y.L., Mills, G., and Wiegel, J. (2006) Thermophilic temperature optimum for crenarchaeol synthesis and its implication for archaeal evolution. Appl Environ Microbiol 72:4419-4422.
Address correspondence to: Gurpreet Kaur

Organic Geochemistry Unit Bristol Biogeochemistry Research Centre School of Chemistry University of Bristol Cantock's Close Bristol BS8 1TS UK

E-mail: preeti.kaur@bristol.ac.uk

Submitted 19 August 2010 Accepted 26 January 2011 
274

GAUR ET AL.

Appendix: Structures of Biomarkers

I. Diglyceride (where $\mathrm{X}$ represents phosphoror glycolipid head group)<smiles>[X]OCC(COC(=O)CCCCCCCCCCCCCCC)OC(=O)CCCCCCCCCCCCCCCCC</smiles>

II. $\beta$-OH fatty acids<smiles>CCCCCCCCCCCCCCCC(O)CC(=O)O</smiles>

Ia. Fatty acids can be free or derive from 1 ; chain length, degree of saturation, and branching can vary

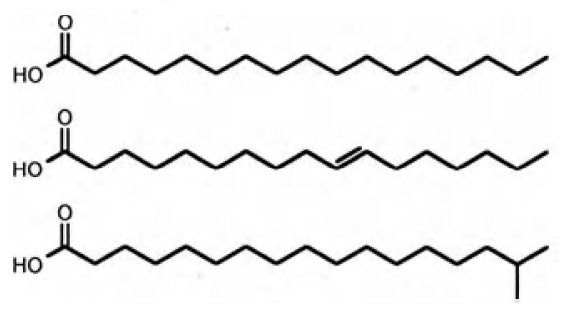

III. Bacteriohopanpolyol $\longrightarrow$ IV. Bishomohopanoic acid

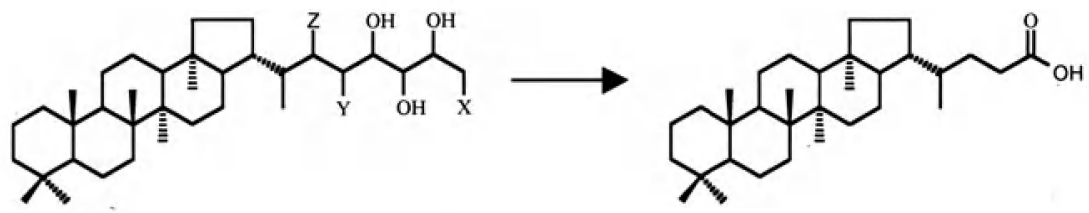

V. Non-isoprenoidal dither<smiles>CCCCCCCCCCCCCCCCCOC(CO)C[OH+]CCCCCCCCCCCCCCCCC</smiles>

VI. Archaeol<smiles>CC(C)CCCC(C)CCCC(C)CCCC(C)CCCC(C)CCCC(C)CCCC(C)CCOC(CO)COCCC(C)C</smiles>

VII. Glycerol dialkyl glycerol tetraethers (GDGTs)

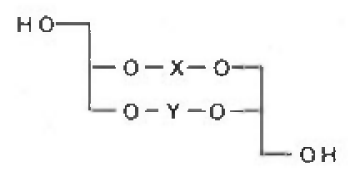

O

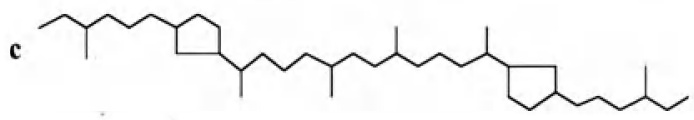

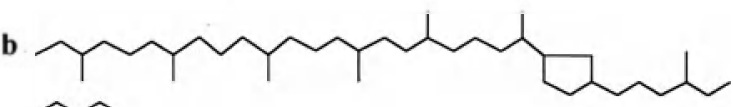

d<smiles>CCC(C)CCCC1CCC(C(C)CCCC(C)CCC(C)CCCC(C)C2CCC(C3CCC(CC)C3)C2)C1</smiles>

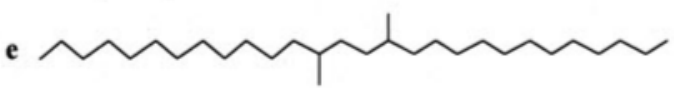

車 